\title{
Peningkatan Akurasi Interpretasi Foto Udara Menggunakan Metode Pembobotan Berbasis Objek untuk Pembuatan Peta Skala 1:5000
}

\author{
MARLONROI LUMBANTOBING, KETUT WIKANTIKA, AGUNG BUDI HARTO
}

\author{
Program Studi Teknik Geodesi dan Geomatika \\ Institut Teknologi Bandung \\ Email: marlonbing801@gmail.com
}

\begin{abstract}
ABSTRAK
Interpretasi citra atau foto udara adalah upaya untuk memahami atau menafsirkan citra atau foto udara sehingga mendapatkan informasi yang akurat dan sesuai dengan objek yang terekam. Kebutuhan akan adanya pengembangan metode untuk meningkatkan akurasi dari interpretasi objek memerlukan kajian metodologi yang disebut analisis citra berbasis objek. Penelitian ini ditujukan untuk menentukan dan menganalisis akurasi dari interpretasi objek secara otomatis dengan metode berbasis objek dengan memberikan bobot yang berbeda untuk setiap kanal. Data yang digunakan adalah foto hasil pemotretan udara format menengah (medium format) dengan resolusi $16 \mathrm{~cm}$. Ekstrak data menggunakan teknik object based image analysis (OBIA). Data diproses berdasarkan bobot yang yang berbeda untuk setiap kanal. Nilai akurasi ditentukan berdasarkan overall accuracy. Overall accuracy merupakan hasil validasi klasifikasi objek dengan ground truth yang diperoleh dari peta garis skala 1:5000 yang diinterpretasi secara visual. Hasil penelitian menunjukkan terjadi peningkatan nilai akurasi dengan pendekatan OBIA jika setiap kanal diberikan bobot yang berbeda dibandingkan dengan bobot yang sama. Peningkatan akurasi paling tinggi dengan bobot (Red=3, Green=4, Blue=3, IR=4, dan DEM=3) menghasilkan akurasi 85,88\%. Hasil akurasi meningkat sebesar 10,27\% dibandingkan dengan interpretasi tanpa pembobotan.
\end{abstract}

Kata kunci: Interpretasi, Peta 1:5000, Klasifikasi, OBIA, Pembobotan, Akurasi

\begin{abstract}
Interpretation of imagery or aerial photo is an attempt to understand or interpret imagery to obtain accurate information and in accordance with the recorded object. The need for developing methods to improve the accuracy of the object interpretation requires assessment methodology which is called as object based image analysis. This study aimed at determining and analyzing the accuracy of the interpretation of the object automatically using object based method by giving different weights to each band. The data used were medium format aerial photos with a resolution of $16 \mathrm{~cm}$. The method of data processing was object based image analysis (OBIA). Data were processed by different weights for each band. Accuracy value is determined based on the overall accuracy. Overall accuracy is the result of the validated object classification with ground truth obtained from the map of 1:5000 which were interpreted visually. The research results showed that the value of the accuracy with OBIA approach increased if each band is given different weights compared with the same weight. The highest accuracy was achieved with weights (Red=3, Green=4, Blue=3, IR=4, and $D E M=3$ ), and resulted overall accuracy $85,88 \%$. Results accuracy increased $10,27 \%$ compared with the interpretation without weighting.
\end{abstract}

Keywords: Interpretation, Map 1:5000, Classification, OBIA, Weighting, Accuracy 


\section{PENDAHULUAN}

Kebutuhan akan adanya pengembangan metode untuk meningkatkan akurasi dari interpretasi objek memerlukan kajian metodologi yang disebut analisis citra berbasis objek (Object Base Image Analysis) atau OBIA (Sari dan Kushardono, 2014). Tidak seperti metode berbasis piksel, metode berbasis objek didasarkan pada segmentasi citra ke area homogen menggunakan bentuk, tekstur dan konteks yang terkait dengan pola sehingga menjadi dasar yang lebih maju untuk analisis citra (Marpu, 2009). Metode OBIA akan menghasilkan klasifikasi yang lebih akurat dan rinci serta waktu yang lebih efisien dibandingkan dengan metode per piksel (Stow dkk., 2007). OBIA merupakan mekanisme otomasi sehingga memberikan efisiensi subtansial jika dibandingkan dengan intrepretasi visual (Aguilar dkk., 2012).

Beberapa penelitian menggunakan metode OBIA berdasarkan unsur spektral warna telah dilakukan sebelumnya, dengan menggunakan citra resolusi tinggi dihasilkan pemetaan wilayah perkotaan dengan nilai akurasi yang baik (Aguilar dkk., 2012; Carleer dkk., 2005; Haralick dkk., 1973; Zan, 2003). Teknik OBIA juga efektif digunakan dalam pemetaan yang bertujuan menginterpretasi tipe permukiman dan perkotaan (Kupkova dkk., 2010; Peijun, 2011). Selain itu teknik serupa digunakan dalam pemetaan tata guna dan tutupan lahan dalam berbagai skala (Greiner dkk., 2008; Lennartz dan Congalton, 2004; Zan, 2003).

Untuk klasifikasi objek selain berdasarkan pada unsur spektral para ahli mencoba menggunakan alternatif lain, antara lain melalui spektral tekstur. Menurut Haralick dkk., (1973), tekstur muncul bersamaan dengan spektral pada citra satelit atau foto udara. Oleh karena itu para ahli mencoba melakukan klasifikasi objek dengan menggunakan tekstur dari foto udara. Klasifikasi objek dari foto udara dengan menggunakan tekstur dilakukan oleh Sari dan Kushardono (2014). Berdasarkan hasil penelitiannya, informasi tekstur dapat menambah tingkat keakuratan hasil klasifikasi objek dibandingkan dengan hanya menggunakan spektral warna. Pemanfaatan tekstur dalam identifikasi tutupan lahan pun digunakan oleh Debeir dkk. (2002) dengan melakukan klasifikasi tutupan lahan di daerah Belgia yang menghasilkan tingkat akurasi yang lebih tinggi dibandingkan bila hanya menggunakan spektral saja. Informasi tekstur pun dilakukan oleh peneliti lain untuk klasifikasi tutupan lahan seperti dilakukan oleh Herold dkk. (2003) dan Wikantika dkk. (2001).

Masalah interpretasi foto udara secara otomatis berbasis objek belum mendapatkan tingkat akurasi yang maksimal, karena pada wilayah yang homogen sulit didapatkan hasil yang maksimal. Hal ini disebabkan secara numerik, citra di daerah homogen mempunyai Digital Number (DN) yang sulit dibedakan karena mempunyai nilai yang relatif kecil antara piksel satu dengan piksel sekitarnya (Hernandi, 2009). Untuk itu diperlukan penelitian atau pengembangan metode yang dapat membantu peningkatan akurasinya.

\section{METODOLOGI}

\subsection{Metode}

Metodologi penelitian yang digunakan adalah dengan pengumpulan data dari pihak terkait, dilanjutkan dengan pengolahan dan analisis data dengan menggunakan software terkait di ruang komputer. Tahap awal yang dilakukan adalah mengumpulkan data-data foto udara dan peta garis hasil interpretasi dari instansi TNI AU yang telah dilaksanakan pengecekan ke lapangan. Data foto udara yang telah diproses menjadi ortofoto digunakan sebagai data untuk proses interpretasi. 
Dalam penelitian ini, informasi unsur permukaan bumi yang terekam dalam foto udara diolah melalui otomasi berbasiskan objek. Gonzales (1993) menyatakan bahwa segmentasi adalah proses pembagian sebuah citra. Dengan segmentasi, informasi satuan terkecil piksel pada citra diubah menjadi per satuan image object. Setiap image object memiliki banyak informasi parameter (feature) yang mendeskripsikan dirinya pada khususnya dan kelasnya pada umumnya ke dalam sejumlah bagian atau objek.

Identifikasi atau klasifikasi unsur melalui parameter tersebut terbagi dalam tranformasi spectral, spectral value, texture value, geometry, dan relation. Metode klasifikasi yang digunakan adalah metode supervised, yaitu dengan memilih training sample area (Sabins, 1986). Proses segementasi akan dilaksanakan kembali dengan memberikan bobot yang berbeda untuk setiap kanal. Tingkat akurasi dari hasil klasifikasi dihitung berdasarkan nilai overall accuracy. Ukuran kualitas hasil klasifikasi berorientasi objek berdasarkan matriks kesalahan yaitu overall accuracy terdiri dari producer accuracy dan user accuracy (Zhan dkk., 2000). Untuk mengetahui tahapan yang lebih jelas mengenai prosedur penelitian, berikut ditampilkan diagram alur penelitian pada gambar 1.

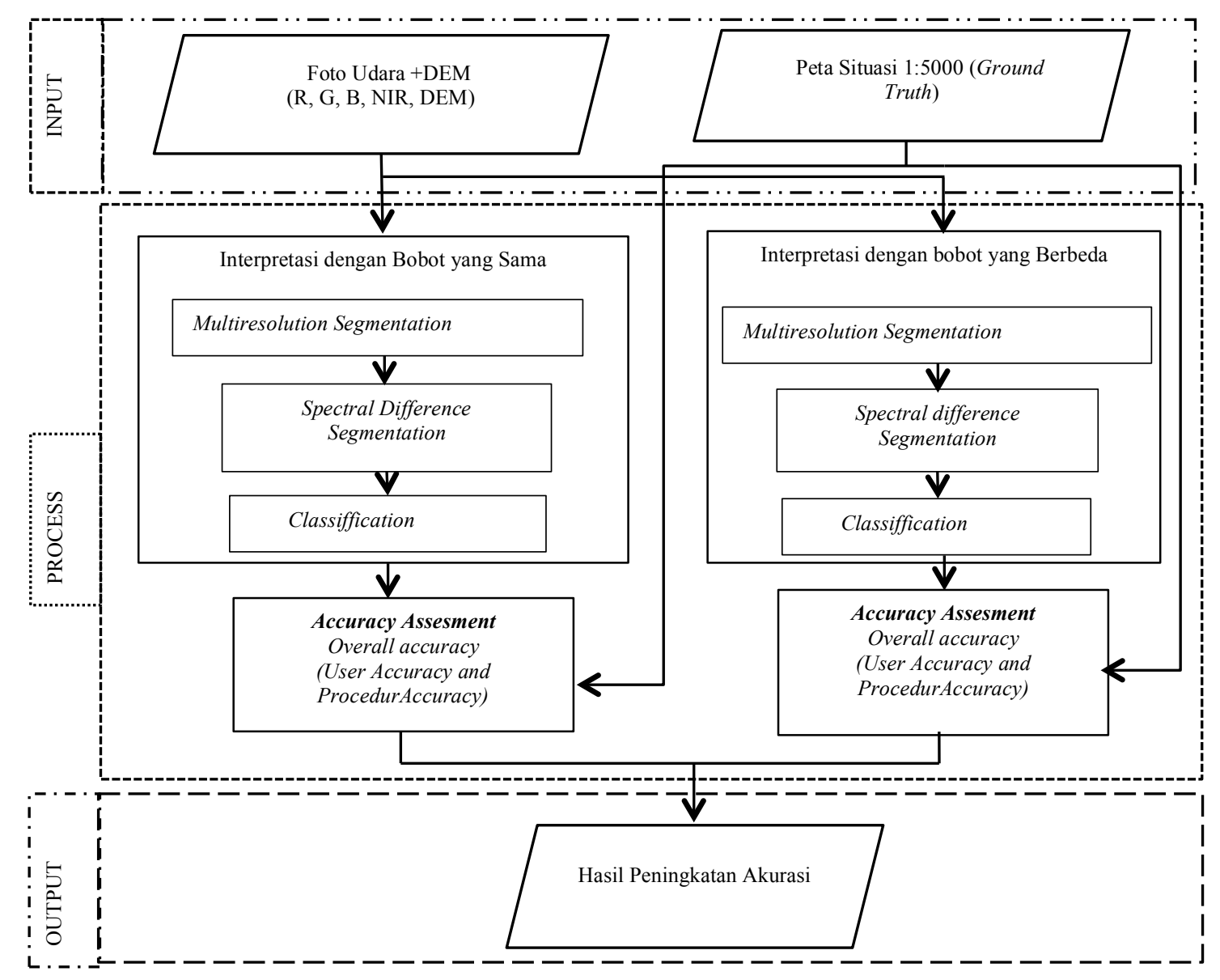

Gambar 1. Diagram Alir Metodologi Penelitian

\subsection{Data dan Lokasi Penelitian}

Data penelitian yang digunakan merupakan hasil pemotretan udara dengan kamera medium format Leica RCD 30 yang dilaksanakan pada tanggal 10 Juni 2014. Tinggi terbang sekitar 
3000 feet diatas permukaan rata-rata tanah wilayah pemotretan. Spesifikasi teknis dari sensor dijelaskan pada tabel 1.

Tabel 1. Spesifikasi Teknis Kamera RCD 30

\begin{tabular}{|c|c|c|c|c|c|c|c|c|}
\hline Sensor & $\begin{array}{c}\text { Type } \\
\text { Sensor }\end{array}$ & $\begin{array}{l}\text { Focus } \\
\text { length }\end{array}$ & $\begin{array}{c}\text { Imagery } \\
\text { Band }\end{array}$ & $\begin{array}{l}C C D \\
\text { Size }\end{array}$ & $\begin{array}{l}\text { Pixel } \\
\text { Size }\end{array}$ & $\begin{array}{c}\text { Angle } \\
\text { across }\end{array}$ & $\begin{array}{c}\text { Angle } \\
\text { long }\end{array}$ & GSD \\
\hline Kamera & Expose & $53 \mathrm{~mm}$ & Red, & 8956 & $6 \mu \mathrm{m}$ & 56 & 44 & $16 \mathrm{~cm}$ \\
\hline RCD 30 & Frame & & $\begin{array}{c}\text { Green, } \\
\text { Blue, Near } \\
\text { Infra Red }\end{array}$ & $\begin{array}{c}x \\
6708 \\
\text { pixels }\end{array}$ & & & & \\
\hline
\end{tabular}

Unsur yang digunakan pada saat pengolahan data yaitu band RGB + NIR ditambahkan data DEM. Data NIR digunakan untuk memisahkan objek vegetasi dan nonvegetasi berdasarkan nilai dari Normalized Difference Vegetation Index (NDVI). Penambahan unsur DEM akan meningkatkan akurasi interpretasi foto udara karena dapat memisahkan objek yang mempunyai tinggi yang berbeda.

Lokasi penelitan adalah Pangkalan Udara Supadio, Pontianak, Kalimantan Barat yang merupakan pangkalan TNI Angkatan Udara. Wilayah ini dipilih karena memiliki kelas objek yang bervariasi sehingga dapat merepresentasikan wilayah yang lain. Kelas objek yang akan diteliti adalah jalan raya, landasan, pemukiman, lahan kosong vegetasi, perkebunan, pepohonan, persawahan, perairan, dan lahan kosong nonvegetasi. Pemilihan kelas objek tersebut disesuaikan berdasarkan standar pembutan peta yang diatur dalam buku petunjuk teknis pembuatan peta 1:5000 yang dikeluarkan oleh TNI AU (Haralick dkk., 1973). Beragamnya kelas objek akan memberikan informasi yang tepat sebagai bahan dasar penelitian ini. Lokasi penelitian disajikan pada gambar 2.

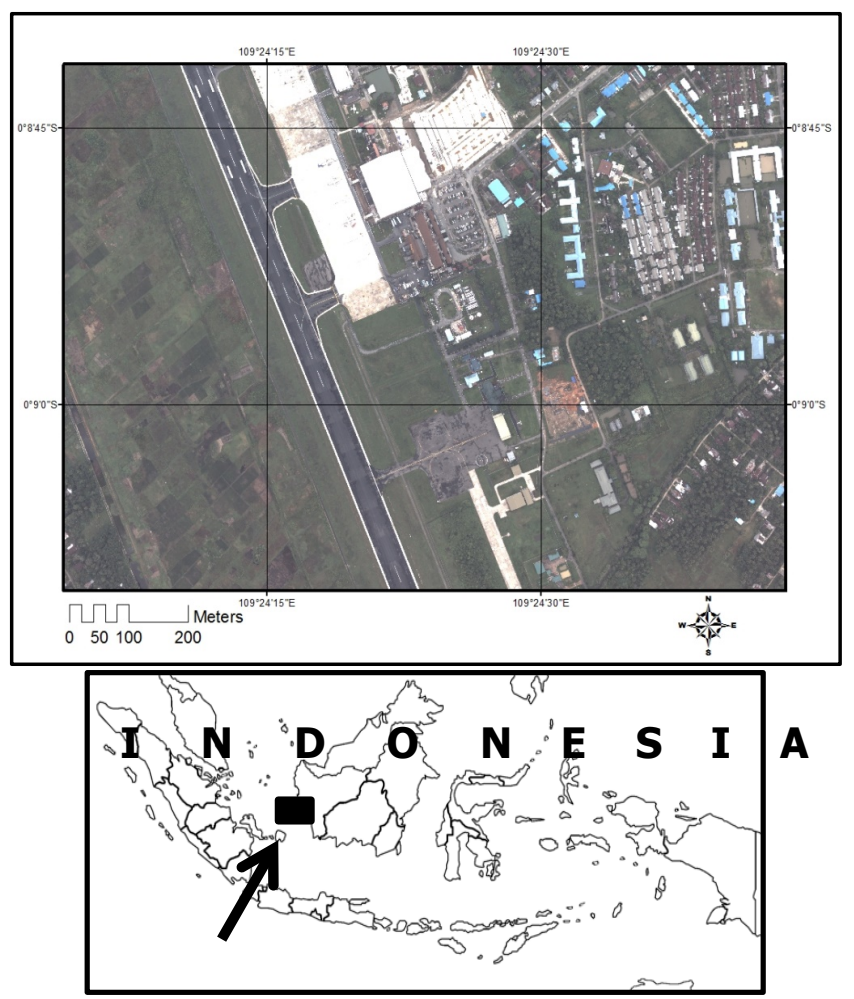

Gambar 2. Lokasi Penelitian 


\subsection{Pengolahan Data}

Secara umum, prosedur dari metode OBIA adalah sebagai berikut: (1) Prapengolahan Citra, (2) Segmentasi, (3) Pengambilan Sampel, (4) Penentuan Ambang Batas Parameter, (5) Klasifikasi, dan (6) Analisis Data (Wasil, 2013; Anonim, 2014).

Prapengolahan data yang dilaksanakan adalah penajaman citra/peningkatan kualitas foto. Peningkatan kualitas foto adalah suatu proses untuk mengubah sebuah foto menjadi foto baru sesuai dengan kebutuhan melalui berbagai cara. Peningkatan kualitas citra yang dilakukan dalam penelitian ini adalah proses peregangan kontras (contrass strecthing) (Lillesand dkk., 2004; Sabins, 1986). Penajaman dengan perentangan kontras memperluas daerah tingkat keabuan/nilai piksel sehingga nilai tersebut dapat digambarkan dalam daerah tingkat keabuan yang penuh (Sabins, 1986). Hal ini dilakukan untuk mengatur kontras dari keseluruhan citra/foto sehingga didapatkan foto yang lebih baik.

Hasil segmentasi citra ditentukan oleh tujuan penelitian, strategi pengambilan keputusan, dan yang lebih spesifik adalah tingkat ketelitian yang diinginkan atau yang diharapkan (Matsuyama, 1987; Pal dan Pal, 1993. Menurut Marini dkk. (2014), jenis segmentasi yang sering digunakan peneliti adalah segmentasi multiresolusi. Segmentasi mulitiresolusi merupakan suatu prosedur optimasi heuristik yang secara lokal meminimumkan rata-rata heterogenitas objek-objek pada citra untuk suatu resolusi tertentu (Parsa, 2013). Parameter yang digunakan dalam prosedur segmentasi multiresolusi antara lain scale, shape, dan compactness (Anonim, 2014). Parameter yang paling penting adalah scale parameter dimana parameter ini menentukan seberapa banyak jumlah piksel yang menyusun satu buah objek (Lizarazo dan Elsner, 2011; Parsa, 2013; Ureyen dkk., 2014). Menurut Sabins (1986), parameter skala merupakan selisih antara digital number tertinggi dan terendah dalam suatu objek. Untuk mendapatkan ketelitian maksimal sesuai dengan SNI No SNI 19-6502.1-2000 bahwa ketelitian peta adalah 0,3 x skala peta (Anonim, 2000; Anonim, 2013a; 2013b), maka untuk skala 1:5000 diharuskan ketelitannya 1,5 meter. Untuk objek yang berukuran 1,5 meter maka dibutuhkan sejumlah 10 piksel. Dengan dasar tersebut dalam penelitian ini dipilih skala parameter yang digunakan adalah kelipatan 10, sedangkan untuk shape dan compactness dipilih nilai tengah 0,5 .

Metode klasifikasi yang digunakan adalah metode supervised, yaitu dengan memilih training sample area (Sabins, 1986). Data diproses menggunakan software Ecognition Developer 8.7.2 (trial version). Paramater yang digunakan untuk klasifikasi dijelaskan pada tabel 2.

Tabel 2. Parameter yang Digunakan untuk Klasifikasi

\begin{tabular}{lllll}
\hline $\begin{array}{c}\text { Spectral } \\
\text { Transformation }\end{array}$ & Spectral Value & Tecture Value & Geometry & Relation \\
\hline NDVI & Brightness value & Homogeneity & Area & Distance to \\
& Mean red & Contrast & width & Real area of \\
& Mean green & Entropy & & \\
& Mean blue & Correlation & & \\
& Mean NIR & & & \\
& Mean DEM & & & \\
\hline
\end{tabular}




\section{HASIL DAN PEMBAHASAN}

Hasil yang didapatkan dalam peneltian ini menunjukkan peningkatan akurasi dari klasifikasi dengan bobot yang berdeda dibandingkan dengan bobot yang sama untuk setiap kanal. Hasil terbaik diperoleh dari kombinasi pembobotan terbaik dari setiap band. Hasil segementasi terbaik yang diperoleh melalui uji coba paramater adalah skala (350), shape $(0,5)$ dan compactness $(0,5)$. Hasil segmentasi dijelaskan pada tabel 3.

Tabel 3. Uji Coba Parameter Skala untuk Segmentasi

\begin{tabular}{|c|c|}
\hline $\begin{array}{c}\text { Skala } \\
\text { Parameter }\end{array}$ & Hasil Segmentasi \\
\hline 200 & $\begin{array}{l}\text { Objek belum terdiferensiasi dengan jelas sebab area } \\
\text { yang seharusnya homogen masih terpisahkan }\end{array}$ \\
\hline 300 & $\begin{array}{l}\text { Sebagian besar objek terdiferensiasi dengan jelas } \\
\text { tetapi masih ada area yang seharusnya homogen } \\
\text { masih terpisahkan }\end{array}$ \\
\hline 350 & $\begin{array}{l}\text { Hampir semua objek terdiferensiasi dengan jelas, } \\
\text { walaupun masih ada sebagian kecil area yang } \\
\text { seharusnya homogen masih terpisahkan }\end{array}$ \\
\hline 400 & $\begin{array}{l}\text { Objek jalan dan lahan kosong tidak terpisahkan } \\
\text { dengan baik. }\end{array}$ \\
\hline
\end{tabular}

Dengan menggunakan training sample, menghitung transformasi spectral, spectral value, tecture value, geometry, relation, dan ground truth yang telah ditentukan maka didapatkan hasil akurasi setiap kanal yang dijelaskan pada gambar 3.



Gambar 3. Grafik Bobot Setiap Kanal terhadap Overall Accuracy

Berdasarkan grafik pada gambar 3 dapat dijelaskan bahwa kanal yang tertinggi akurasinya adalah kanal hijau dengan bobot $(G=4)$, kemudian kanal biru dengan bobot $(B=3)$, selanjutnya DEM dengan bobot $(\mathrm{DEM}=3)$, selanjutnya kanal infra merah dengan bobot $(\mathrm{IR}=4)$, dan akurasi yang terendah pada kanal merah dengan bobot $(R=3)$. Hasil tersebut sesuai dengan karakteristik wilayah yang dominan vegetasi, yang mana kanal yang paling berpengaruh untuk pemetaan wilayah vegetasi adalah kanal hijau. Peningkatan akurasi 
merupakan hasil dari pengaruh peningkatan procedure dan user accuracy. Hasil akurasi tertinggi dan terendah untuk pemebobotan kanal terbaik dijelaskan pada Tabel 4.

Tabel 4. Hasil Akurasi Tertinggi dan Terendah untuk Setiap Band

\begin{tabular}{|c|c|c|c|c|c|c|}
\hline Band & $\begin{array}{c}\text { Bobot } \\
\text { Terbaik }\end{array}$ & $\begin{array}{c}\text { Overall } \\
\text { accuracy }\end{array}$ & $\begin{array}{l}\text { Producer } \\
\text { accuracy } \\
\text { tertinggi }\end{array}$ & $\begin{array}{l}\text { Producer } \\
\text { accuracy } \\
\text { terendah }\end{array}$ & $\begin{array}{c}\text { User } \\
\text { accuracy } \\
\text { tertinggi }\end{array}$ & $\begin{array}{c}\text { User } \\
\text { accuracy } \\
\text { terendah }\end{array}$ \\
\hline $\begin{array}{l}\text { Bobot } \\
\text { Sama }\end{array}$ & & 0,7561 & $\begin{array}{l}\text { Pepohonan } \\
(0,8244)\end{array}$ & $\begin{array}{c}\text { Jalan Raya } \\
(0,4337)\end{array}$ & $\begin{array}{c}\text { Lahan } \\
\text { Vegetasi } \\
(0,9678)\end{array}$ & $\begin{array}{c}\text { Jalan Raya } \\
(0,4924)\end{array}$ \\
\hline Red & $R=3$ & 0,8008 & $\begin{array}{c}\text { Pepohonan } \\
(0,9662)\end{array}$ & $\begin{array}{c}\text { Persawahan } \\
(0,3150)\end{array}$ & $\begin{array}{c}\text { Landasan } \\
(0,941)\end{array}$ & $\begin{array}{c}\text { Jalan Raya } \\
(0,4842)\end{array}$ \\
\hline Green & $\mathrm{G}=4$ & 0,8248 & $\begin{array}{c}\text { Pepohonan } \\
(0,9662)\end{array}$ & $\begin{array}{c}\text { Perswahan } \\
(0,5021)\end{array}$ & $\begin{array}{c}\text { Landasan } \\
(0,9458)\end{array}$ & $\begin{array}{c}\text { Jalan Raya } \\
(0,5500)\end{array}$ \\
\hline Blue & $B=3$ & 0,8053 & $\begin{array}{c}\text { Pepohonan } \\
(0,9662)\end{array}$ & $\begin{array}{c}\text { Persawahan } \\
(0,4735)\end{array}$ & $\begin{array}{c}\text { Landasan } \\
(0,9457)\end{array}$ & $\begin{array}{c}\text { Jalan Raya } \\
(0,5032)\end{array}$ \\
\hline $\begin{array}{l}\text { Infra } \\
\text { Red }\end{array}$ & $\mathrm{IR}=4$ & 0,8030 & $\begin{array}{c}\text { Pepohonan } \\
(0,9662)\end{array}$ & $\begin{array}{c}\text { Jalan Raya } \\
(0,6173)\end{array}$ & $\begin{array}{c}\text { Landasan } \\
(0,9457)\end{array}$ & $\begin{array}{c}\text { Jalan Raya } \\
(0,5007)\end{array}$ \\
\hline DEM & $\mathrm{DEM}=3$ & 0,8070 & $\begin{array}{l}\text { Pepohonan } \\
(0,9662)\end{array}$ & $\begin{array}{c}\text { Jalan Raya } \\
(0,6300)\end{array}$ & $\begin{array}{c}\text { Landasan } \\
(0,9476)\end{array}$ & $\begin{array}{c}\text { Jalan Raya } \\
(0,5003)\end{array}$ \\
\hline
\end{tabular}

Dari tabel 5-2 di atas dapat dijelaskan bahwa overall accuracy tertinggi dihasilkan untuk bobot $\mathrm{R}=3, \mathrm{G}=4, \mathrm{~B}=3, \mathrm{IR}=4$, dan $\mathrm{DEM}=3$. Producer accuracy terbaik adalah objek pepohonan dan terendah jalan raya dan persawahan. User accuracy tebaik adalah landasan dan terendah jalan raya. Hal tersebut terjadi karena untuk jalan raya banyak ditutupi oleh pohon, dan mempunyai kemiripan dengan pemukiman dan landasan. Sawah mempunyai kemiripan dengan perkebunan sehingga ada beberapa perkebunan yang diklasifikasikan sebagai sawah.

Untuk mendapatkan hasil akurasi yang lebih tinggi maka dilakukan klasifikasi dengan mengkombinasikan bobot terbaik dengan dua kombinasi yaitu berdasarkan bobot terbaik dan berdasarkan urutan persentasi dari bobot terbaik. Kombinasi pertama menggunakan bobot $\mathrm{R}=3, \mathrm{G}=4, \mathrm{~B}=3, \mathrm{IR}=4$, dan $\mathrm{DEM}=3$. Kombinasi kedua adalah berdasarkan urutan nilai overall accuracy, dimana yang terendah diberikan bobot (1) dan yang tertinggi diberikan (5). Bobot yang digunakan untuk kombinasi kedua adalah Green (5), Blue (4), DEM (3), IR (2), dan Red (1). Hasil Klasifikasi dijelaskan pada tabel 5. Berdasarkan Tabel 5 dapat dijelaskan bahwa akurasi terbaik adalah klasifikasi dengan kombinasi pembobotan $(R=3, G=4, B=3$, $\mathrm{IR}=4$, dan $\mathrm{DEM}=3$ ) dengan nilai overall accuracy sebesar 0,8588 dan KIA sebesar 0,8289. Terjadi peningkatan akurasi sebesar $10,27 \%$. Untuk menjelaskan peningkatan overall accuracy dilakukan analisis user dan procedure accuracy untuk setiap objek. Hasil analisis akurasi setiap objek untuk klasifikasi terbaik dijelaskan pada tabel 6 . 
Tabel 5. Hasil Akurasi Klasifikasi dengan Kombinasi Pembobotan

\begin{tabular}{cclcc}
\hline $\begin{array}{c}\text { Kombinasi Pembobotan } \\
\text { (R, G, B, IR,DEM) }\end{array}$ & $\begin{array}{c}\text { Jumlah } \\
\text { Objek }\end{array}$ & $\begin{array}{c}\text { Overall } \\
\text { Accuray }\end{array}$ & KIA & Keterangan \\
\hline Bobot Sama & 10213 & 0.7561 & 0,7060 & Bobot Sama \\
$(3,4,3,4,3)$ & 12249 & 0.8588 & 0.8298 & Peningkatan akurasi \\
$(1,5,4,2,3)$ & 12250 & 0.8336 & 0.7992 & Peningkatan akurasi \\
\hline
\end{tabular}

Tabel 6. Hasil Peningkatan Akurasi dengan Kombinasi Pembobotan $(R=3, G=4$, $B=3, I R=4$, dan $D E M=3)$

\begin{tabular}{lcccccc}
\hline \multirow{2}{*}{ Kelas Objek } & \multicolumn{2}{c}{ Bobot Sama } & \multicolumn{2}{c}{$\begin{array}{c}\text { Pembobotan } \\
\text { Kombinasi }\end{array}$} \\
\cline { 2 - 7 } & $\begin{array}{c}\text { Producer } \\
\text { Accuracy } \\
(\%)\end{array}$ & $\begin{array}{c}\text { User } \\
\text { Accuracy } \\
(\%)\end{array}$ & $\begin{array}{c}\text { Producer } \\
\text { Accuracy } \\
(\%)\end{array}$ & $\begin{array}{c}\text { User } \\
\text { Accuracy } \\
(\%)\end{array}$ & $\begin{array}{c}\text { Producer } \\
\text { Accuracy } \\
(\%)\end{array}$ & $\begin{array}{c}\text { Uscer } \\
\text { Accuracy } \\
(\%)\end{array}$ \\
\hline Pemukiman & 69,51 & 69,05 & 85,4 & 78,96 & 15,89 & 9,91 \\
Landasan & 82,65 & 87,56 & 83,53 & 96,46 & 0,88 & 8,90 \\
Jalan Raya & 53,37 & 49,24 & 64,00 & 64,23 & 10,63 & 14,99 \\
Perairan & 81,93 & 69,42 & 90,02 & 73,97 & 8,09 & 4,55 \\
Lahan N Vegetasi & 68,35 & 69,42 & 95,66 & 79,31 & 27,31 & 9,89 \\
Persawahan & 53,96 & 75,34 & 77,30 & 86,53 & 23,34 & 11,19 \\
Pepohonan & 82,44 & 70,90 & 96,62 & 86,43 & 14,18 & 15,53 \\
Perkebunan & 70,40 & 67,77 & 85,51 & 83,47 & 15,11 & 15,70 \\
Lahan Vegetasi & 78,83 & 89,41 & 90,20 & 93,83 & 11,37 & 4,42 \\
\hline
\end{tabular}

Berdasarkan tabel 5-6 di atas dapat dijelaskan bahwa producer accuracy dan user accuracy meningkat unruk semua objek. Peningkatan producer accuracy yang paling tinggi adalah lahan kosong nonvegetasi sebesar $27,31 \%$ dan persawahan sebesar $23,34 \%$. Peningkatan user accuracy yang paling tinggi adalah pepohonan sebesar $15,53 \%$ dan jalan raya $14,99 \%$. Hal ini menunjukkan bahwa pembobotan kombinasi terbaik dari setiap band menghasilkan peningkatan akurasi yang terbaik juga. Hasil klasifikasi terbaik disajikan pada gambar 3.

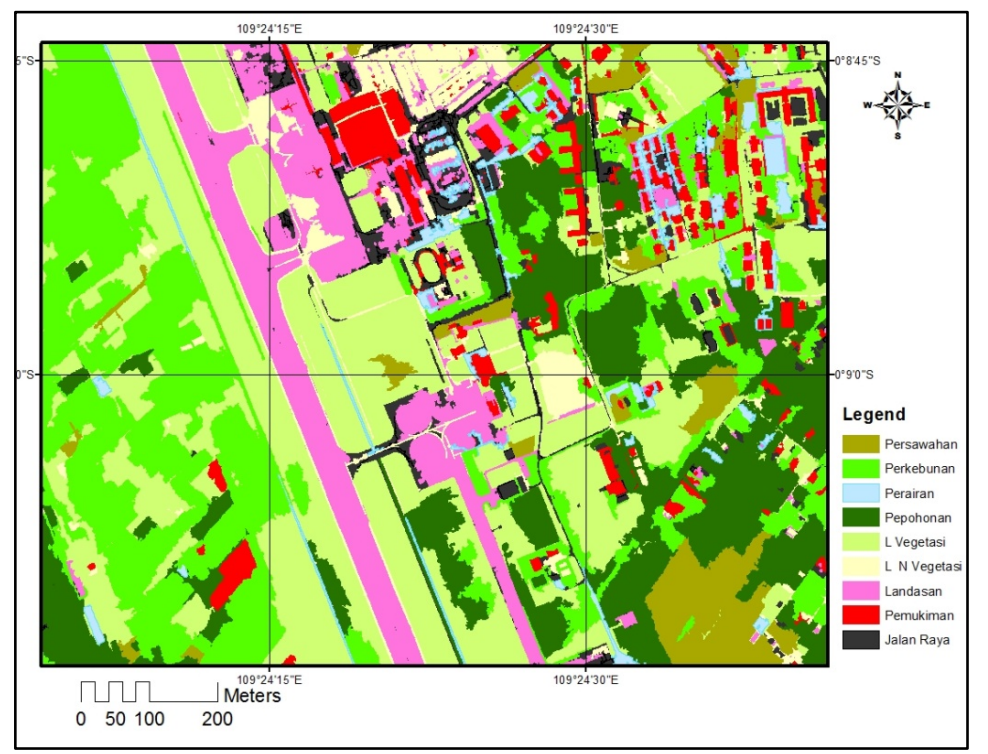

Gambar 4. Klasifikasi Berbasis Objek dengan Kombinasi Pembobotan $\mathrm{R}=3, \mathrm{G}=4$, $\mathrm{B}=3$, $\mathrm{IR}=4$, dan $\mathrm{DEM}=3$ 


\section{KESIMPULAN DAN SARAN}

\subsection{Kesimpulan}

Berdasarkan hasil penelitian, dapat diambil beberapa kesimpulan sebagai berikut:

1. Interpretasi foto udara berbasis objek dengan memperhitungkan pengaruh bobot dari setiap band dapat meningkatkan akurasi yang lebih baik dibandingkan dengan tanpa pembobotan.

2. Kombinasi bobot terbaik pada penelitian ini adalah (Red=3, Green=4, Blue=3, IR=4, dan $\mathrm{DEM}=3$ ) menghasilkan akurasi $85,88 \%$. Terjadi peningkatan akurasi sebesar $10,27 \%$ dibandingkan dengan interpretasi tanpa pembobotan.

3. Pengaruh bobot paling tinggi adalah band green dengan bobot Green $=4$ dengan tingkat akurasi $82,48 \%$, sedangkan pengaruh bobot paling rendah adalah band merah dengan tingkat akurasi $80,08 \%$.

\subsection{Saran}

Dengan melihat hasil observasi, analisis, dan pengalaman empiris dalam penelitian ini, untuk pengembangan penelitian selanjutnya, penulis menyarankan penelitian tentang metode untuk memecahkan masalah objek yang saling menutupi, terutama objek pohon yang menutupi objek lain.

\section{DAFTAR PUSTAKA}

Aguilar, M.A., Vicente, R., Aguilar, F.J., Fernández, A., dan Saldaña, M.M. (2012). Optimizing Object-Based Classification In Urban Environments Using Very High Resolution Geoeye-1 Imagery. ISPRS Annals of the Photogrammetry, Remote Sensing and Spatial Information Sciences, Volume I-7. XXII ISPRS CongresS, 25 August - 1 September 2012, Melbourne, Australia.

Anonim (2000). Spesifikasi Teknis Peta Rupabumi Skala 1:10.000, Badan Standardisasi Nasional, SNI 19-6502.1-2000.

Anonim (2013a). Peraturan Pemerintah Republik Indonesia Nomor 8 Tahun 2013 tentang Ketelitian Peta Rancana Tata Ruang, Jakarta.

Anonim (2013b). Peraturan Kapala Staf Angkatan Udara Kep 20/V/2013 tentang Buku Petunjuk Teknis TNI AU tentang Pembuatan Peta Situasi Pangkalan Udara, Jakarta.

Anonim, (2014): Trimble eCognition $\mathbb{R}$ Developer Reference Book. Trimble Documentation, Munchen, Germany.

Carleer, A., Debeir, O., dan Wolf, E. (2005). Assessment of Very High Spatial Resolution Satellite Image Segmentations, Photogrammetric Engineering and Remote Sensing Vol.71: 1285-1294.

Debeir, O., Van den Steen, I., Latlanne, P., Van Ham, P., dan Wolf, E. (2002). Textural and Contextual Land-Cover Classification Using Single and Multiple Classifier Systems, Photogrammetric Engineering \& Remote Sensing, 68:6, 597-605.

Gonzales, R.C. (1993). Digital Imaging processing. Addison-Wesley publishing Company.

Greiner, M., Labrecque, S., Garneau, M., dan Tremblay, A., (2008). Accuracy Assessment Method for Wetland Object-Based Classification, Canadian Journal of Remote Sensing, Vol. 34, No. 2, 398-413.

Haralick, R. M., Shanmugan, K., dan Dinstein I. (1973). Textural Features for Image Segmentation, IEEE Transactions on Systems, Man and Cybernetics, Vol. SMC-3 No. 6, 610-621. 
Herold, M., Gardner, M., dan Roberts, D. (2003). Spectral Resolution Requirements for Mapping Urban Areas, IEEE Transactions on Geoscience and Remote Sensing Vol. 41: 1907-1919.

Hernandi, A. (2009). Peningkatan Keberhasilan Pencocokan Citra Menggunakan Metode Pembobotan Proporsional pada Kanal Berbeda untuk Citra Teramplifikasi dalam Ranah Frekuensi, Disertasi, Institut Teknologi Bandung.

Kupkova, L., Potuckova, M., Kopalova, I., dan Kolar, J. (2010). Object Based Image Analysis for Urbanized Areas, Regional Office of South Bohemia Ceske Budejovoice. Holland.

Lennartz, S.P. dan Congalton, R.G. (2004). Classifying and mapping forest cover types using Ikonos imagery in the northeastern United States, Proceedings of the ASPRS Annual Conference, Denver, Colorado, American Society for Photogrametry and Remote Sensing, Bethesda, Maryland.

Lizarazo, I dan Elsner, P. (2011). Segmentation of Remotely Sensed Imagery: Moving from Sharp Objects to Fuzzy Regions. Dalam Pei-Gee Ho (Ed.), Image Segmentation, ISBN: 978-953-307-228-9.

Lillesand, T. M., Kiefer, R. W., dan Chipman, J. W. (2004). Remote Sensing and Image Interpretation. New York: John Wiley and Sons.

Marini, Y., Emiyati, Hawariyah, S., dan Hartuti, M. (2014). Perbandingan Metode Klasifikasi Supervised Maximum Likelihood dengan Klasifikasi Berbasis Objek untuk Inventarisasi Lahan Tambak di Kabupaten Maros. Seminar Nasional penginderaan Jauh. Pusat Pemanfaatan Penginderaan Jauh, LAPAN.

Marpu, P. R. (2009). Geographic Object-based Image Analysis, Thesis, Faculty of Geosciences, Geo-Engineering and Mining of the Technische Universit at Bergakademie Freiberg Germany.

Matsuyama, T. (1987). Knowledge-Based Aerial Image Understanding Systems and Expert Systems for Image Processing, IEEE Transactions on Geosciences and Remote Sensing, Vol. GE.-25.

Pal, N. R. dan Pal, S. K. (1993). A Review of Image Segmentation Techniques, Pattern Recognition Vol. 26 No.9, 1277-1294.

Parsa, I. M. (2013). Optimalisasi Parameter Segmentasi untuk Pemetaan Lahan Sawah Menggunakan Citra Satelit Landsat (Studi Kasus Padang Pariaman dan Tanggamus Lampung), Jurnal Penginderaan Jauh, Vol. 10 No. 1 29-40.

Peijun, L. (2011). A Multilevel hierarchical Image Segmentation Method For Urban Impervious Surface Mapping Using Very High Resolution Imagery, IEEE Journal Of Selected Topics in Applied Erath Observation and Remote Sensing, Vol. 4 No. 1 103-116.

Sabins, F. F. (1986). Remote Sensing Principles and Interpretation, United States of America: Remote Sensing Enterprises, Inc.

Sari, N. M. dan Kushardono, D. (2014). Klasifikasi Penutup Lahan Berbasis Objek pada Data Foto UAV untuk Mendukung Penyediaan Informasi Penginderaan Jauh Skala Rinci. Jurnal Penginderaan Jauh, Vol. 11 No. 2, 114-127.

Stow, D., Lopez, A., Lippitt, C., Hinton, S., dan Weeks, J. (2007). Object Based Classification of Residential Land Use within Accra, Ghana Based on QuickBird Satellite Data, International Journal of Remote Sensing, Vol. 28, No. 22, 5167-5173.

Ureyen, S., Huttich C., dan Schmullius C. (2014). Modeling Growing Stock Volume Using SAR Data and OBIA, Journal of Remote Sensing Technology. Department for Earth Observation, Friedrich-Schiller-University Jena, Löbdergraben 32, 07742 Jena, Germany. Vol. 2 Iss. 1, 25-34.

Wasil, R. A. (2013). Kombinasi Pohon Keputusan dan Analisis Citra Hirarki Berbasiskan Objek untuk Pemetaan Tutupan Lahan sesuai SNI 7645:2010, Tesis Magister Teknik, Institut Teknologi Bandung. 
Wikantika, K., Uchida, S., dan Yamammoto, A. (2001). An Evaluation of the Use of Integrated Spectral and Textural Features to Identify Agricultural Land Cover Types in Pangalengan, West Java, Indonesia, JARQ, 38:2, 137-148.

Zan, Q. (2003). A Hierarchical Object-Based Approach for Urban Land-Use Classification from Remote Sensing Data, ITC Dissertation No.103.

Zhan, X., DeFries, R. S., Townshend, J. R. G., Dimiceli, C., Hansen, M. C., Huang, C., dan Sohlberg, R. (2000). The 250m Global Land Cover Change Product from the Moderate Resolution Imaging Spectroradiometer of NASA's Earth Observing System, International Journal of Remote Sensing, Vol. 21: No. 6, 1433-1460. 